\title{
Light and $\mathrm{O} 2$ microenvironments in two contrasting diatom-dominated coastal sediments
}

Article in Marine Ecology Progress Series · March 2016

DOI: $10.3354 /$ meps 11630

CITATIONS

0

5 authors, including:

\section{Paulo Cartaxana}

University of Copenhagen

57 PUBLICATIONS 756 CITATIONS

SEE PROFILE

\section{Sónia Cruz}

University of Aveiro

21 PUBLICATIONS 449 CITATIONS

SEE PROFILE

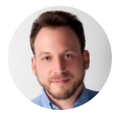

Johannes W. Goessling

University of Copenhagen

4 PUBLICATIONS 116 CITATIONS

SEE PROFILE

Michael Kühl

University of Copenhagen

336 PUBLICATIONS 9,779 CITATIONS

SEE PROFILE

Some of the authors of this publication are also working on these related projects:

Project
Seagrass microbiome: potential beneficial effects of rhizosphere microbes on seagrass health View project

BenthicLIF View project 


\title{
Light and $\mathrm{O}_{2}$ microenvironments in two contrasting diatom-dominated coastal sediments
}

\author{
Paulo Cartaxana ${ }^{1, *}$, Lourenço Ribeiro ${ }^{2,3}$, Johannes W. Goessling ${ }^{1}$, Sónia Cruz ${ }^{1,4}$, \\ Michael Kühl ${ }^{1,5}$
}

${ }^{1}$ Marine Biological Section, Department of Biology, University of Copenhagen, Strandpromenaden 5, $3000 \mathrm{Helsingør,}$ Denmark

${ }^{2}$ Université de Nantes, Mer Molécules Santé EA2160, Faculté des Sciences et des Techniques, 44322 Nantes Cedex 3, France

${ }^{3}$ Centro de Ciências do Mar e Ambiente (MARE), Faculdade de Ciências da Universidade de Lisboa, Campo Grande, 1749-016 Lisboa, Portugal

${ }^{4}$ Departamento de Biologia \& CESAM - Centro de Estudos do Ambiente e do Mar, Universidade de Aveiro, Campus de Santiago, 3810-193 Aveiro, Portugal

${ }^{5}$ Plant Functional Biology and Climate Change Cluster, University of Technology Sydney, Sydney, NSW 2007, Australia

\begin{abstract}
The close coupling of photosynthesis and light was studied in 2 contrasting diatomdominated coastal sediments (sand and mud flats) using $\mathrm{O}_{2}$ microelectrodes and fiber-optic microprobes for scalar irradiance. The diatom community of the muddy sediment was composed almost exclusively of motile epipelic species, whereas in the sandy sediment similar contributions of epipsammic and epipelic diatoms were observed. The attenuation coefficient of scalar irradiance $\left(K_{0}\right)$ was significantly higher in the mud, where light was attenuated exponentially with depth from the sediment surface. In the sand, scalar irradiance levels increased in the first $0.1-0.2 \mathrm{~mm}$ due to high scattering and low absorption. Attenuation of scalar irradiance was highest for wavelengths of absorption by major diatom photopigments (chlorophylls and carotenoids). Higher areal and volumetric rates of $\mathrm{O}_{2}$ respiration were found in illuminated sediments than those in the dark, resulting from an increase in both $\mathrm{O}_{2}$ concentration and penetration depth and a direct stimulation of heterotrophic processes. A lower light acclimation index $\left(E_{\mathrm{k}}\right)$ was observed for the muddy sediment community, indicating lower light acclimation compared to the sandy sediment community. Areal and volumetric rates of photosynthesis were $\sim 3$ times higher in the muddy sediment. We conclude that higher photosynthetic rates in the finer sediment were determined by (1) a thinner and more densely populated photic zone, where the contribution of active photopigments to total light absorption relative to that of photosynthetically inactive components was higher, and (2) differences in diatom species composition and dominant life-strategies, specifically the capacity of cells to actively search for optimal light microenvironments in the fine-grained sediment.
\end{abstract}

KEY WORDS: Microsensors · Diatoms · Migration · Photosynthesis $\cdot$ Respiration $\cdot$ Scalar irradiance Resale or republication not permitted without written consent of the publisher

\section{INTRODUCTION}

Microphytobenthic communities inhabiting the intertidal and shallow subtidal mud and sand flats of estuaries and coastal zones are largely dominated by diatoms and/or cyanobacteria. These organisms have been identified as some of the most important pri- mary producers in coastal ecosystems (MacIntyre et al. 1996), playing a significant role as (1) facilitators of carbon transfer among trophic levels (Bellinger et al. 2009), (2) mediators of nutrient cycling and exchange across the sediment-water interface (Sundbäck et al. 2000) and (3) efficient sediment stabilizers (Underwood \& Paterson 2003). 
The microenvironment of these densely populated microphytobenthic communities is complex and characterized by steep physical and chemical gradients, including very strong light attenuation. Microenvironmental heterogeneity in benthic communities is more pronounced than in planktonic systems, at a spatial scale comparable to the size and distance between the individual organisms (Underwood \& Kromkamp 1999). Therefore, studies of microphytobenthic photosynthesis require specialized tools to assess the distribution of light and photosynthetic activity at relevant spatial scales. The use of fiberoptic scalar irradiance microprobes in combination with $\mathrm{O}_{2}$ microsensors is an ideal way to resolve how the steep gradients of light intensity and spectral composition in sediments affect microbenthic photosynthesis and other aspects of the photobiology of microphytobenthos in their natural environments (Kühl et al. 1996, Kühl 2005).

Microphytobenthos colonizing sediments live in a diffuse light field with a strong component of scattered light that is harvested from all directions (Kühl \& Jørgensen 1992, 1994); thus, measurements of downwelling irradiance can significantly underestimate the light availability for photosynthesis in such communities (Kühl et al. 1994). It is therefore of paramount importance to relate photosynthesis at a given point to scalar irradiance, i.e. the integral of radiance incident from all directions around a point in space (Lassen et al. 1992, Kühl \& Jørgensen 1994). Light in sedimentary environments is subject to intense absorption but also to a high degree of scattering due to the high density of microalgae, detritus and sediment particles. This has several important consequences that may impact microphytobenthic photosynthesis, namely (1) strong light attenuation resulting in an extremely narrow photic zone, (2) local enhancement of scalar irradiance at the sediment surface due to intense scattering, and (3) rapid change in light quality with depth resulting from differential absorption: a decrease of the wavelengths coinciding with photopigment absorption maxima compared to other wavelengths in the light spectrum (Lassen et al. 1992, Ploug et al. 1993, Kühl \& Jørgensen 1994, Kühl et al. 1994, 1996).

Benthic diatom communities have traditionally been divided into 2 main groups with regard to the life-strategies they exhibit: the epipelon and the epipsammon (e.g. Round 1965, Admiraal 1984). The epipelon consists of motile diatoms that can move freely between sediment particles and usually dominate in muddy sediments, whereas the epipsammon mostly comprises smaller, non-motile diatoms that are attached to sand grains, and therefore are found more commonly in sandy substrata. As this nomenclature represents an oversimplification, a more refined classification has recently been proposed, uncoupling motility or attachment from sediment type (e.g. Ribeiro et al. 2013, Barnett et al. 2015). This includes differentiation within the epipsammic group between non-motile species, firmly attached (either stalked or adnate) to sand particles, and motile forms that can move within the sphere of individual sand grains. Motile epipelic diatoms may actively search for optimal light microenvironments, exhibiting vertical migratory rhythms determined by diurnal and tidal cycles (Round \& Palmer 1966, Pinckney \& Zingmark 1991, Underwood et al. 2005) and irradiance levels (Kromkamp et al. 1998, Perkins et al. 2010, Vieira et al. 2011). Epipsammon-dominated sand flat communities do not show such migratory patterns and photoregulate exclusively through physiological mechanisms (Jesus et al. 2009, Cartaxana et al. 2011).

Although several studies have characterized light and/or $\mathrm{O}_{2}$ microenvironments in benthic systems dominated by cyanobacteria and/or diatoms (e.g. Lassen et al. 1992, Ploug et al. 1993, Kühl et al. 1996, Glud et al. 2002, Brotas et al. 2003, Hancke \& Glud 2004, Al-Najjar et al. 2010, 2012), such measurements have never been done together in fine muddy sediments with a typically migrating diatom community in order to assess the close coupling of photosynthesis and light. In this study, $\mathrm{O}_{2}$ microelectrodes and fiber-optic microprobes for scalar irradiance were applied to resolve the vertical variability of $\mathrm{O}_{2}$, light and photosynthesis in 2 contrasting diatomdominated coastal sediments: highly cohesive fine mud and coarse sandy sediment. We hypothesized that differences in photosynthetic rates in diatomdominated sediments with distinct particle size composition would be determined by light absorption patterns and dominant cell life-strategies. Oxygen budgets and a detailed description of the diatom taxonomic composition of the 2 studied benthic communities are presented.

\section{MATERIALS AND METHODS}

\section{Sediment sampling and experimental set-up}

Sediment samples (2 cm depth) were collected from an estuarine mud flat in Lisbon, Portugal $\left(38^{\circ} 47^{\prime} 46.7^{\prime \prime} \mathrm{N}, 09^{\circ} 05^{\prime} 32.4^{\prime \prime} \mathrm{W}\right)$ and a sandy beach in Helsingør, Denmark (56 $\left.02^{\prime} 48.5^{\prime \prime} \mathrm{N}, 12^{\circ} 36^{\prime} 07.3^{\prime \prime} \mathrm{E}\right)$ using a rectangular acrylic corer $(19.7 \times 7.8 \times 2 \mathrm{~cm})$, 
and were transferred with minimal disturbance to custom-made acrylic flow-through chambers. In the laboratory, a stable laminar flow of aerated seawater was maintained above the sediment surface (water layer depth: $1.5 \mathrm{~cm}$; temperature: $16^{\circ} \mathrm{C}$; salinity: 30 ) using a submersible water pump (Rena Flow 400) connected to the flow chamber and immersed in a temperature-controlled water reservoir.

Sediments were first exposed to an incident downwelling photon irradiance $\left(E_{\mathrm{d}}\right.$ Table 1 provides a list of abbreviations) of photosynthetically active radiation (PAR, 400-700 nm) of $75 \mu \mathrm{mol}$ photons $\mathrm{m}^{-2} \mathrm{~s}^{-1}$ for approximately $24 \mathrm{~h}$. The sediments were illuminated vertically from above with a fiber-optic tungsten halogen lamp (KL-2500, Schott) equipped with a collimating lens, and $E_{\mathrm{d}}$ was measured with a calibrated photon irradiance meter (ULM-500, Walz) equipped with a planar cosine collector (LI-190, LiCor). Sediments were exposed at each experimental photon irradiance $\left(0,250,500\right.$ and $1000 \mu \mathrm{mol}$ photons $\left.\mathrm{m}^{-2} \mathrm{~s}^{-1}\right)$ for at least $45 \mathrm{~min}$ prior to $\mathrm{O}_{2}$ and scalar photon irradiance measurements. Changes in photon irradiance were achieved without spectral distortion by adjusting the aperture size on the fiber-optic halogen lamp.

Sediment grain size composition was determined by sequential sediment sieving, evaluating the relative contribution (\% dry weight) of the size fractions: >1000, 1000-500, 500-250, 250-125, 125-63 and $<63 \mu \mathrm{m}$.

\section{Microphytobenthos biomass and taxonomic composition}

Sediment samples (approximately the upper $2 \mathrm{~mm}$ ) were collected for biomass estimation and taxonomic composition analysis by scraping the surface with a scalpel. Approximately $100 \mathrm{mg}$ of sediment were extracted for $24 \mathrm{~h}$ with $3 \mathrm{ml}$ of $90 \%$ acetone for biomass estimation. Chlorophyll a ( $\mathrm{chl}$ a) concentrations were determined on pigment extracts by spectrophotometry (UV-2101PC, Shimadzu) using the method of Jeffrey \& Humphrey (1975). Approximately $3 \mathrm{ml}$ of sediment was collected for taxonomic composition analysis and placed in $5 \mathrm{ml}$ polypropylene tubes, to which $1 \mathrm{ml}$ of a $2.5 \%$ glutaraldehyde solution was added, and stored at $4{ }^{\circ} \mathrm{C}$ for later processing. Cells were extracted from the sediment following an isopycnic separation technique using silica sol Ludox ${ }^{\circledR}$ HS-40 (Sigma-Aldrich) that separates the organic material from mineral particles, and is thus able to remove both migratory and non-migratory fractions of the diatom assemblages, as well as cyanobacteria,
Table 1. Definitions of abbreviations

\begin{tabular}{|c|c|}
\hline Symbo & Definition \\
\hline$\alpha$ & $\begin{array}{l}\text { Initial slope of the photosynthesis vs. irradiance } \\
\text { curve }\end{array}$ \\
\hline$\Phi$ & Sediment porosity \\
\hline DBL & Diffusive boundary layer \\
\hline$D_{0}$ & Molecular diffusion coefficient of $\mathrm{O}_{2}\left(\mathrm{~cm}^{2} \mathrm{~s}^{-1}\right)$ \\
\hline$D_{\mathrm{s}}$ & Sediment diffusion coefficient of $\mathrm{O}_{2}\left(\mathrm{~cm}^{2} \mathrm{~s}^{-1}\right)$ \\
\hline$E_{0}$ & Photon scalar irradiance ( $\mu \mathrm{mol}$ photons $\left.\mathrm{m}^{-2} \mathrm{~s}^{-1}\right)$ \\
\hline$E_{\mathrm{d}}$ & $\begin{array}{l}\text { Downwelling photon irradiance ( } \mu \text { mol photons } \\
\mathrm{m}^{-2} \mathrm{~s}^{-1} \text { ) }\end{array}$ \\
\hline$E_{\mathrm{k}}$ & Light acclimation index ( $\mu \mathrm{mol}$ photons $\mathrm{m}^{-2} \mathrm{~s}^{-1}$ ) \\
\hline$E_{\mathrm{C}}$ & Compensation irradiance $\left(\mu \mathrm{mol}\right.$ photons $\left.\mathrm{m}^{-2} \mathrm{~s}^{-1}\right)$ \\
\hline$J_{\text {up }}$ & $\begin{array}{l}\text { Upward } \mathrm{O}_{2} \text { flux through the DBL } \\
\left(=P_{\mathrm{n}}, \mathrm{nmol} \mathrm{O}_{2} \mathrm{~cm}^{-2} \mathrm{~s}^{-1}\right)\end{array}$ \\
\hline$J_{\text {down }}$ & $\begin{array}{l}\text { Downward } \mathrm{O}_{2} \text { flux from the photic zone } \\
\left(\mathrm{nmol} \mathrm{O}_{2} \mathrm{~cm}^{-2} \mathrm{~s}^{-1}\right)\end{array}$ \\
\hline$K_{0}$ & $\begin{array}{l}\text { Attenuation coefficient of scalar irradiance } \\
\left(\mathrm{mm}^{-1}\right)\end{array}$ \\
\hline PAR & $\begin{array}{l}\text { Photosynthetically active radiation } \\
\left(400-700 \mathrm{~nm}, \mu \mathrm{mol} \text { photons } \mathrm{m}^{-2} \mathrm{~s}^{-1}\right)\end{array}$ \\
\hline$P_{z}$ & $\begin{array}{l}\text { Volumetric gross photosynthesis at depth } z \\
\left(\mathrm{nmol} \mathrm{O}_{2} \mathrm{~cm}^{-3} \mathrm{~s}^{-1}\right)\end{array}$ \\
\hline$P_{\mathrm{g}}$ & Gross areal photosynthesis $\left(\mathrm{nmol} \mathrm{O} \mathrm{Cm}^{-2} \mathrm{~s}^{-1}\right)$ \\
\hline$P_{\mathrm{n}}$ & $\begin{array}{l}\text { Net areal photosynthesis } \\
\left(=J_{\text {up }}, \mathrm{nmol} \mathrm{O} \mathrm{O}_{2} \mathrm{~cm}^{-2} \mathrm{~s}^{-1}\right)\end{array}$ \\
\hline$P_{\mathrm{n}, \mathrm{phot}}$ & $\begin{array}{l}\text { Net areal photosynthesis of the photic zone } \\
\left(=\left|J_{\text {up }}\right|+\left|J_{\text {down }}\right|, n m o l O_{2} \mathrm{~cm}^{-2} \mathrm{~s}^{-1}\right)\end{array}$ \\
\hline$P_{\max }$ & $\begin{array}{l}\text { Maximal photosynthetic capacity } \\
\left(\mathrm{nmol} \mathrm{O}_{2} \mathrm{~cm}^{-2} \mathrm{~s}^{-1}\right)\end{array}$ \\
\hline$R_{\text {light }}$ & $\begin{array}{l}\text { Areal respiration in the light } \\
\left(=P_{\mathrm{g}}-P_{\mathrm{n}}, \mathrm{nmol} \mathrm{O}_{2} \mathrm{~cm}^{-2} \mathrm{~s}^{-1}\right)\end{array}$ \\
\hline$R_{\text {dark }}$ & Areal respiration in the dark $\left(\mathrm{nmol} \mathrm{O}_{2} \mathrm{~cm}^{-2} \mathrm{~s}^{-1}\right)$ \\
\hline$R_{\text {phot }}$ & $\begin{array}{l}\text { Areal respiration within the photic zone } \\
\left(=P_{\mathrm{g}}-P_{\mathrm{n}, \mathrm{phot}}, \mathrm{nmol} \mathrm{O}_{2} \mathrm{~cm}^{-2} \mathrm{~s}^{-1}\right)\end{array}$ \\
\hline
\end{tabular}

euglenids and other microphytobenthic algal groups (Ribeiro 2010). Total cell counts were made directly from the extract on an Olympus BX50 optical microscope, at $400 \times$ magnification.

Diatom identification and cell counts were made on permanent slides of cleaned diatom material, mounted in Naphrax ${ }^{\mathrm{TM}}$, on a Zeiss Axioskop 50 microscope equipped with differential interference contrast optical microscopy. The observation of the extracts showed that weakly-silicified diatoms, like Atheya and Cylindrotheca, were an important part of the assemblages. Therefore, to avoid the underestimation of these fragile genera, 2 types of slides were made: one from diatom material incinerated in a muffle-furnace for $2 \mathrm{~h}$ at $450^{\circ} \mathrm{C}$ to preserve fragile specimens; and one from diatom material that was oxidized by hydrogen peroxide $(30 \%)$ at $90^{\circ} \mathrm{C}$ for $4 \mathrm{~h}$, thus destroying the slightly silicified frustules, but allowing better identification of very small taxa. In both cases, >400 frustules/valves were counted. 
After determining the relative percentage of the fragile diatoms (i.e. Cylindrotheca and Atheya spp.), the relative abundance (percentage) of the other taxa was determined in the oxidized slide taking into consideration what was previously established for fragile specimens (Ribeiro 2010). Diatom identification mainly followed Ribeiro (2010) and Witkowski et al. (2000) and references therein.

Biovolume assessment followed the estimates presented by Snoeijs et al. (2002) and Ribeiro et al. (2013). In the cases of taxa that were not available in those works, biovolume calculations were made following Hillebrand et al. (1999). Size-classes and lifestrategy information were primarily taken from Ribeiro (2010) and references herein, but followed the growth-form groups proposed by Barnett et al. (2015): epipelon (EPL), motile epipsammon (EPM-M) and non-motile epipsammon (EPM-NM) (no tychoplanktonic species - those that can live both in the sediment and in the water column - were observed). Diversity of the 2 studied microphytobenthic communities was calculated using the Shannon index:

$$
H^{\prime}=-\sum_{i=1}^{S} p_{i} \log _{\mathrm{e}} p_{i}
$$

\section{Microprofiling of $\mathrm{O}_{2}$ concentration and gross photosynthesis}

Depth profiles of dissolved $\mathrm{O}_{2}$ concentrations were measured with fast responding $\left(t_{90}<0.5 \mathrm{~s}\right)$ Clark-type microelectrodes (tip diameter $25 \mu \mathrm{m}$, OX-25, Unisense A/S) at vertical steps of $0.1 \mathrm{~mm}$. The $\mathrm{O}_{2}$ microelectrodes were connected to a pA meter (Unisense A/S) and signals were recorded via a USB-interfaced A/D-converter (DCR16, Pyro Science) through dedicated PC-controlled data acquisition software (Profix, Pyro Science). The $\mathrm{O}_{2}$ microsensors were linearly calibrated at experimental temperature and salinity from measurements in aerated seawater as well as in seawater made anoxic by the addition of sodium sulphite. The $\mathrm{O}_{2}$ microsensors were mounted on a motor-driven micromanipulator (MU1, Pyro Science), which was interfaced to a desktop computer and controlled with the Profix software. Surface positioning of the microsensors was done while observing the sediment with a PC-interfaced USB digital microscope (AD7013MZT Dino-Lite, AnMo Electronics). The microsensors were inserted into the sediment at an angle of $45^{\circ}$ relative to the vertical incident light beam to avoid self-shading. The software automatically accounted for the sensor insertion angle; all depths are given in vertical distances.
Volumetric gross photosynthesis rates $\left(P_{z}\right.$, nmol $\mathrm{O}_{2}$ $\mathrm{cm}^{-3} \mathrm{~s}^{-1}$ ) were measured at $0.1 \mathrm{~mm}$ depth intervals at the higher experimental photon irradiance (400$700 \mathrm{~nm}, 1000 \mu \mathrm{mol}$ photons $\mathrm{m}^{-2} \mathrm{~s}^{-1}$ ) using the microelectrode light-dark shift technique (Revsbech \& Jørgensen 1983). In this method, the gross rate of photosynthesis is estimated as the initial $\mathrm{O}_{2}$ depletion rate at a specific depth during the first few seconds after light is briefly turned off (see also Glud et al. 1992). Depth integration over the sediment photic zone yielded areal gross photosynthesis rates $\left(P_{\mathrm{g}}, \mathrm{nmol} \mathrm{O}_{2}\right.$ $\left.\mathrm{cm}^{-2} \mathrm{~s}^{-1}\right)$.

\section{Flux calculations of net photosynthesis and respiration}

Sediment net areal photosynthesis $\left(P_{\mathrm{n}}\right)$ was calculated from steady-state $\mathrm{O}_{2}$ profiles in the light using the flux of $\mathrm{O}_{2}\left(J_{\text {up }}\right)$ into the overlaying water through the diffuse boundary layer (DBL) as calculated by Fick's first law of diffusion (Kühl et al. 1996):

$$
J_{\text {up }}=P_{\mathrm{n}}=-D_{0} \mathrm{~d} C / \mathrm{d} z
$$

where $D_{0}$ is the molecular $\mathrm{O}_{2}$ diffusion coefficient at experimental salinity and temperature (from Table for seawater and gases, Unisense $\mathrm{A} / \mathrm{S}$ ) and $\mathrm{d} C / \mathrm{d} z$ is the linear concentration gradient in the DBL. Net photosynthetic rates as a function of the incident photon irradiance, $P_{\mathrm{n}}(E)$, were fitted with an exponential model (Webb et al. 1974), with an extra term, $R$, to account for $\mathrm{O}_{2}$ consumption (Spilling et al. 2010):

$$
P_{\mathrm{n}}(E)=P_{\max }\left(1-\exp ^{-\alpha E / P \max }\right)+R
$$

where $P_{\max }$ represents the maximum photosynthetic capacity and $\alpha$ is the initial slope of the photosynthesis vs. irradiance curve. The compensation irradiance $\left(E_{c}\right)$, i.e. the irradiance at which total $\mathrm{O}_{2}$ production and consumption in the sediment balanced each other, was determined when $P_{\mathrm{n}}(E)=0$. The light acclimation index, $E_{\mathrm{k}}$, i.e. the irradiance at onset of photosynthesis saturation was calculated from $E_{\mathrm{k}}=P_{\max } / \alpha$.

Sediment areal respiration in the dark $\left(R_{\text {dark }}\right)$ was calculated by Eq. (2) as the linear flux of $\mathrm{O}_{2}$ into the sediment through the DBL. The areal respiration of the sediment in the light $\left(R_{\text {light }}\right)$ was calculated as the difference between gross and net photosynthesis $\left(P_{\mathrm{g}}-P_{\mathrm{n}}\right)$. Net photosynthesis and respiration were also calculated for the photic zone alone (Kühl et al. 1996). The areal net photosynthesis of the photic zone $\left(P_{\mathrm{n}, \text { phot }}\right)$ was calculated as the absolute sum of 
the flux of $\mathrm{O}_{2}$ into the overlaying water across the DBL $\left(J_{\text {up }}\right)$ and the flux into the biofilm below the photic zone $\left(J_{\text {down }}\right)$. Downward $\mathrm{O}_{2}$ flux at the lower boundary of the photic zone was calculated as:

$$
J_{\text {down }}=-\Phi D_{\mathrm{s}} \mathrm{d} C / \mathrm{d} z
$$

where $\Phi$ is the sediment porosity, and $D_{\mathrm{s}}$ is the sediment diffusion coefficient, which was calculated from the porosity and $D_{0}$ according to Iversen \& Jørgensen (1993). Sediment porosity was calculated from core slicing and subsequent drying of known volumes of sediment. The areal respiration of the photic zone $\left(R_{\text {phot }}\right)$ was then calculated as $P_{\mathrm{g}}-P_{\mathrm{n}, \mathrm{phot}}$. Average volumetric rates of $\mathrm{O}_{2}$ respiration of distinct zones of the sediment were calculated by dividing areal respiration rates determined from the flux calculations with the depth of the photic zone or the $\mathrm{O}_{2}$ penetration depth (Kühl et al. 1996).

\section{Light measurements}

Spectral measurements of scalar irradiance $\left(E_{0}\right)$ were done at $0.1 \mathrm{~mm}$ vertical depth intervals using a scalar irradiance microprobe connected to a fiberoptic spectrometer (USB2000+, Ocean Optics) interfaced to a PC running spectral acquisition software (Spectra Suite, Ocean Optics). The scalar irradiance microprobe consisted of a small diffusing sphere (80 $\mu \mathrm{m}$ diameter) cast on the coated tip of a tapered optical fiber (Rickelt et al. 2016). The position and insertion angle of the scalar irradiance probe was controlled as described above for the $\mathrm{O}_{2}$ microelectrodes.

Photon scalar irradiance of PAR was obtained by integrating scalar irradiance spectra from 400 to $700 \mathrm{~nm}$. The downwelling spectral scalar irradiance (i.e. $E_{\mathrm{d}}$ ) at the sediment surface was measured by positioning the scalar irradiance microprobe over a black non-reflective light well at the same position relative to the vertically incident, collimated light field as the sediment surface. Scalar irradiance spectra at various depths in the sediment were normalized to the known incident downwelling photon irradiance at the sediment surface. Attenuation coefficients of photon scalar irradiance were calculated from the depth profiles of spectral scalar irradiance as (Kühl 2005):

$$
K_{0}=\ln \left(E_{1} / E_{2}\right) /\left(z_{2}-z_{1}\right)
$$

where $K_{0}$ is the vertical spectral attenuation coefficient of scalar irradiance, and $E_{1}$ and $E_{2}$ are the spectral scalar irradiance measured at depths $z_{1}$ and $z_{2}$ in the sediment (where $z_{2}>z_{1}$ ).

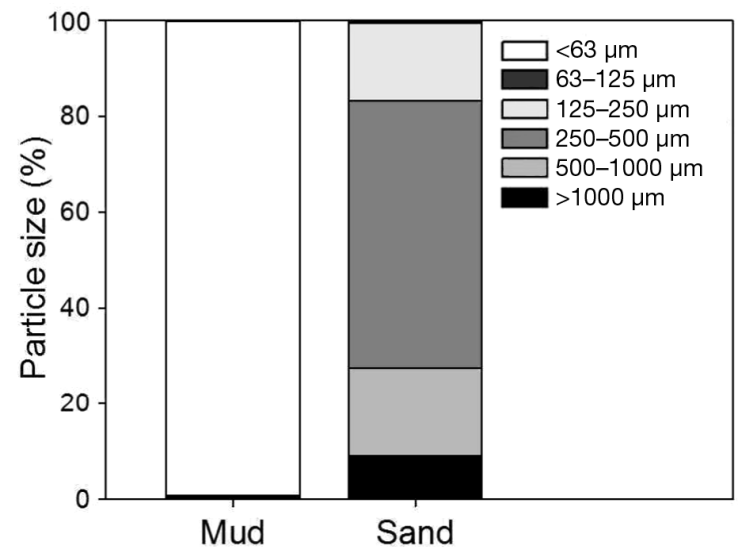

Fig. 1. Particle size fractions (\%) of the muddy (mud) and sandy (sand) coastal sediments

\section{RESULTS}

\section{Sediment particle size and porosity}

The 2 studied coastal sediments differed significantly regarding particle size composition. More than $99 \%$ of the muddy sediment was composed of particles $<63 \mu \mathrm{m}$ (Fig. 1), with a porosity of 0.9 . In the sandy sediment, the particle size distribution was dominated by medium sand of $250-500 \mu \mathrm{m}$ with $56 \%$ dry weight, followed by coarse and fine sand (5001000 and $125-250 \mu \mathrm{m}$ size-classes) with 18 and $16 \%$ dry weight, respectively. Small stones and broken shells $(>1000 \mu \mathrm{m})$ were also a significant part $(9 \%)$ of the sediment. Particles $<125 \mu \mathrm{m}$ represented less than $1 \%$ of the sediment (Fig. 1), with a porosity of 0.6 .

\section{Microphytobenthos biomass and community composition}

Concentrations of chl a were higher in the muddy sediment, but only when expressed on a per dry weight basis: $229 \pm 12$ and $94 \pm 23 \mu \mathrm{g} \mathrm{chl} \mathrm{a} \mathrm{g}{ }^{-1}$ for the mud and sandy sediment, respectively. On a volumetric basis, similar chl a concentrations were observed: $108 \pm 6$ and $138 \pm 34 \mu \mathrm{g} \mathrm{chl} \mathrm{a} \mathrm{cm}^{-3}$, for the mud and sandy sediment, respectively. Diatoms dominated the microphytobenthic communities of both studied coastal sediments, with a relative abundance of 95.6 and $90 \%$ of total cells in the muddy and sandy sediment, respectively. In the muddy sediment, cyanobacteria of the genera Oscillatoria and Merismopedia and euglenophytes represented only 1.5 and $2.9 \%$ of the total cell number. In the sandy sediment, the 
Table 2. Diatoms (28 taxa) collected from the muddy coastal sediment site (Lisbon, Portugal), including details of their relative abundance (\%), biovolume $\left(\mu \mathrm{m}^{3}\right)$ and life-form (EPL: epipelon; EPM-M: motile epipsammon; EPM-NM: non-motile epipsammon). Relative abundances were also allocated to 4 size-classes which comprised the average cell biovolumes of $<100$, $100-250,250-1000$ and $>1000 \mu^{3}$

\begin{tabular}{|c|c|c|c|c|}
\hline Taxon & Abundance & Biovolume & Size-class & Life-form \\
\hline Biremis lucens (Hustedt) Sabbe, Witkowski \& Vyverman & 0.1 & 439 & $250-1000$ & EPM-NM \\
\hline Cylindrotheca closterium (Ehrenberg) Reimann \& Lewin & 15.7 & 247 & $100-250$ & EPL \\
\hline Cylindrotheca cf. gracilis (Brébisson in Kützing) Grunow & 5.5 & 639 & $250-1000$ & EPL \\
\hline Entomoneis paludosa var. paludosa (W. Smith) Reimer in Patrick \& Reime & 6.3 & 2869 & $>1000$ & EPL \\
\hline Fallacia subforcipata (Hustedt) Mann & 0.1 & 204 & $100-250$ & EPM-M \\
\hline Gyrosigma acuminatum (Kützing) Rabenhorst & 2.0 & 20790 & $>1000$ & EPL \\
\hline Gyrosigma fasciola (Ehrenberg) Griffith \& Henfrey & 9.4 & 6614 & $>1000$ & EPL \\
\hline Gyrosigma cf. limosum Sterrenburg \& Underwood & 0.3 & 7436 & $>1000$ & EPL \\
\hline Gyrosigma wansbeckii (Donkin) Cleve & 0.2 & 27104 & $>1000$ & EPL \\
\hline Luticola mutica (Kützing) Mann & 0.2 & 425 & $250-1000$ & EPL \\
\hline Navicula arenaria Hustedt & 0.2 & 3290 & $>1000$ & EPL \\
\hline Navicula cf. biskanterae Hustedt & 0.1 & 507 & $250-1000$ & EPL \\
\hline Navicula flagellifera Hustedt & 0.3 & 757 & $250-1000$ & EPL \\
\hline Navicula gregaria Donkin & 3.2 & 271 & $250-1000$ & EPL \\
\hline Navicula pargemina Underwood \& Yallop & 0.1 & 74 & $<100$ & EPL \\
\hline Navicula perminuta Grunow in van Heurck & 0.3 & 126 & $100-250$ & EPL \\
\hline Navicula phyllepta Kützing & 0.3 & 228 & $100-250$ & EPL \\
\hline Navicula cf. phyllepta Kützing & 18.6 & 137 & $100-250$ & EPL \\
\hline Navicula spartinetensis Sullivan \& Reimer & 34.5 & 299 & $250-1000$ & EPL \\
\hline Nitzschia cf. dubia W. Smith & 0.2 & 5529 & $>1000$ & EPL \\
\hline Nitzschia cf. distans Gregory & 0.2 & 1343 & $>1000$ & EPL \\
\hline Nitzschia sp.1 & 0.2 & 82 & $<100$ & EPL \\
\hline Petrodictyon gemma (Ehrenberg) Mann in Round, Crawford \& Mann & 0.5 & 22764 & $>1000$ & EPL \\
\hline Plagiotropis vitrea (W. Smith) Grunow & 0.3 & 6676 & $>1000$ & EPL \\
\hline Pleurosigma angulatum sensu W. Smith emend. Sterrenburg & 0.3 & 38153 & $>1000$ & EPL \\
\hline Staurophora salina (W. Smith) Mereschkowsky & 0.5 & 2278 & $>1000$ & EPL \\
\hline Surirella sp.1 sensu Ribeiro (2010) & 0.3 & 3529 & $>1000$ & EPL \\
\hline Tryblionella gracilis W. Smith & 0.1 & 2880 & $>1000$ & EPL \\
\hline
\end{tabular}

same 2 genera of cyanobacteria were present at a relative abundance of $8.3 \%$, while green microalgae and euglenophytes only made minor contributions (1.6 and $0.1 \%$, respectively).

Diatom species richness $(46)$ and diversity $\left(H^{\prime}=\right.$ $2.87)$ were higher in the sand than in the muddy sediment (28 and $H^{\prime}=1.99$, respectively) (Tables $2 \& 3$ ). The sandy sediment community was also more diverse in terms of life-strategies, with motile (18 species) and non-motile epipsammon (11) coexisting with epipelic (17) diatoms (Table 3). In the mud, epipelic species were mainly observed (26 out of a total of 28 species) (Table 2). In terms of relative abundance, the muddy sediment was almost exclusively inhabited by epipelic diatoms $(99.8 \%)$, while in the sand, epipelic and epipsammic diatoms exhibited a similar contribution $(\sim 50 \%)$ to the microphytobenthic community (Tables $2 \& 3$ ). In the muddy sediment, most of the identified species were large diatoms, with 14 species having a biovolume of $>1000 \mathrm{\mu m}^{3}$. In contrast, most of the identified diatoms in the sand were small, with 33 species having a bio- volume $<250 \mu^{3}$. Nevertheless, medium sized diatoms $\left(250\right.$ to $1000 \mu^{3}$ ) dominated both muddy and sandy communities in terms of relative abundance (in both cases, ca. $45 \%$ ).

The microphytobenthic communities of the 2 studied sediments were also quite distinct in terms of diatom composition, sharing only 2 species (Cylindrotheca closterium and Navicula gregaria). The muddy sediment was dominated by species of the genera Navicula (57.6\% relative abundance), particularly $N$. spartinetensis $(34.5 \%)$ and $N$. cf. phyllepta $(18.6 \%)$ (Table 2). In the sand, the most representative species were the epipelic Navicula sp.1 (15.6\%) and the non-motile epipsammic Anorthoneis vortex (12.4\%) and Attheya decora (11.2\%) (Table 3).

\section{Scalar irradiance}

Depth profiles of photon scalar irradiance were rather different between the 2 studied coastal sediments (Fig. 2): while scalar irradiance levels at the 
Table 3. Diatoms (46 taxa) collected from the sandy coastal sediment site (Helsingør, Denmark), including details of their relative abundance (\%), biovolume $\left(\mu^{3}\right)$ and life-form (EPL: epipelon; EPM-M: motile epipsammon; EPM-NM: non-motile epipsammon). Relative abundances were also allocated to 4 size-classes which comprised the average cell biovolumes of $<100,100-250,250-1000$ and $>1000 \mu^{3}$

\begin{tabular}{|c|c|c|c|c|}
\hline Taxon & Abundance & Biovolume & Size-class & Life-form \\
\hline Biremis lucens (Hustedt) Sabbe, Witkowski \& Vyverman & 0.1 & 439 & $250-1000$ & EPM-NM \\
\hline Achnanthes cf. amoena Hustedt & 0.2 & 85 & $<100$ & EPM-M \\
\hline Amphora subacutiuscula Schoeman & 3.9 & 1194 & $>1000$ & EPM-M \\
\hline Amphora cf. tenerrima Aleem \& Hustedt & 0.2 & 120 & $100-250$ & EPL \\
\hline Amphora wisei (Salah) Simonsen & 0.2 & 110 & $100-250$ & EPM-M \\
\hline Anaulus balticus Simonsen & 0.4 & 52 & $<100$ & EPM-NM \\
\hline Anorthoneis vortex Sterrenburg & 12.4 & 790 & $250-1000$ & EPM-NM \\
\hline Astartiella punctifera (Hustedt) Witkowski \& Lange-Bertalot & 2.4 & 468 & $250-1000$ & EPM-M \\
\hline Attheya decora T. West & 11.2 & 2363 & $>1000$ & EPM-NM \\
\hline Biremis ambigua (Cleve) Mann & 0.2 & 23488 & $>1000$ & EPM-NM \\
\hline Cavinula sp. & 0.2 & 104 & $100-250$ & EPM-M \\
\hline Cocconeis hauniensis Witkowski & 0.7 & 54 & $<100$ & EPM-NM \\
\hline Cocconeis pelta A. Schmidt & 0.2 & 221 & $100-250$ & EPM-NM \\
\hline Cocconeis peltoides Hustedt & 0.4 & 175 & $100-250$ & EPM-NM \\
\hline Cylindrotheca closterium (Ehrenberg) Reimann \& Lewin & 0.9 & 247 & $100-250$ & EPL \\
\hline Fallacia cryptolyra (Brockmann) Stickle \& Mann & 0.2 & 162 & $100-250$ & EPM-M \\
\hline Fragilaria cf. cassubica Witkowski \& Lange-Bertalot & 0.2 & 81 & $<100$ & EPM-NM \\
\hline Grammatophora oceanica Ehrenberg & 0.2 & 4126 & $>1000$ & EPM-NM \\
\hline Halamphora cf. abuensis (Foged) Levkov & 0.4 & 110 & $100-250$ & EPL \\
\hline Navicula aleksandrae Lange-Bertalot, Bogaczewicz-Adamczak \& Witkowski & 1.1 & 76 & $<100$ & EPM-M \\
\hline Navicula biskanterae Hustedt & 0.2 & 98 & $<100$ & EPM-M \\
\hline Navicula cf. celinei Witkowski, Metzeltin \& Lange-Bertalot & 0.2 & 122 & $100-250$ & EPM-M \\
\hline Navicula cf. perminuta Grunow in van Heurck & 2.0 & 68 & $<100$ & EPL \\
\hline Navicula diserta Hustedt & 5.9 & 54 & $<100$ & EPM-M \\
\hline Navicula germanopolonica Witkowski \& Lange-Bertalot & 2.6 & 132 & $100-250$ & EPM-M \\
\hline Navicula gregaria Donkin & 8.4 & 831 & $250-1000$ & EPL \\
\hline Navicula sp.1 & 15.6 & 381 & $250-1000$ & EPL \\
\hline Navicula sp.2 & 0.4 & 158 & $100-250$ & EPL \\
\hline Navicula sp.3 & 0.2 & 64 & $<100$ & EPL \\
\hline Navicula sp.4 & 0.4 & 205 & $100-250$ & EPL \\
\hline Navicula sp. 5 & 0.2 & 338 & $250-1000$ & EPL \\
\hline Navicula sp.6 & 0.9 & 58 & $<100$ & EPL \\
\hline Navicula viminoides Giffen & 0.7 & 96 & $<100$ & EPM-M \\
\hline Nitzschia aurariae Cholnoky & 0.7 & 64 & $<100$ & EPL \\
\hline Nitzschia cf. distans Gregory & 2.8 & 1343 & $>1000$ & EPL \\
\hline Nitzschia dubiiformis Hustedt & 0.2 & 1189 & $>1000$ & EPL \\
\hline Nitzschia sp.2 & 0.7 & 354 & $250-1000$ & EPL \\
\hline Opephora guenter-grassii (Witkowski \& Lange-Bertalot) Sabbe \& Vyverman & 0.2 & 62 & $<100$ & EPM-NM \\
\hline Opephora mutabilis (Grunow) Sabbe \& Vyverman & 0.2 & 167 & $100-250$ & EPM-NM \\
\hline Parlibellus cf. calvus Witkowski, Metzeltin \& Lange-Bertalot & 5.5 & 252 & $250-1000$ & EPL \\
\hline Planothidium delicatulum (Kützing) Round \& Bukhtiyarova morphotype 1 & 3.1 & 140 & $<100$ & EPM-M \\
\hline Planothidium delicatulum (Kützing) Round \& Bukhtiyarova morphotype 3 & 0.2 & 91 & $100-250$ & EPM-M \\
\hline Planothidium deperditum (Giffen) Witkowski & 0.4 & 54 & $<100$ & EPM-M \\
\hline Planothidium cf. lemmermannii (Hustedt) Morales & 0.9 & 75 & $<100$ & EPM-M \\
\hline Planothidium sp.1 & 0.7 & 100 & $100-250$ & EPM-M \\
\hline Planothidium sp.2 & 0.2 & 108 & $100-250$ & EPM-M \\
\hline Seminavis cf. strigosa (Hustedt) Danielidis \& Economou-Amilli & 10.9 & 171 & $100-250$ & EPL \\
\hline
\end{tabular}

sediment surface were similar in both, reaching $\sim 120 \%$ of incident downwelling photon irradiance, light was attenuated differently. In the muddy sediment, light was attenuated exponentially with depth starting from the surface, while photon scalar irradiance levels in the sand increased over the first
$0.1-0.2 \mathrm{~mm}$ to $130-150 \%$ of incident downwelling irradiance, followed by an exponential light attenuation starting from $\sim 0.2$ to $0.4 \mathrm{~mm}$ depth, depending on the incident downwelling irradiance (Fig. 2). Light attenuation coefficients of PAR were distinctively different between the 2 coastal sediments, with $K_{0}$ val- 


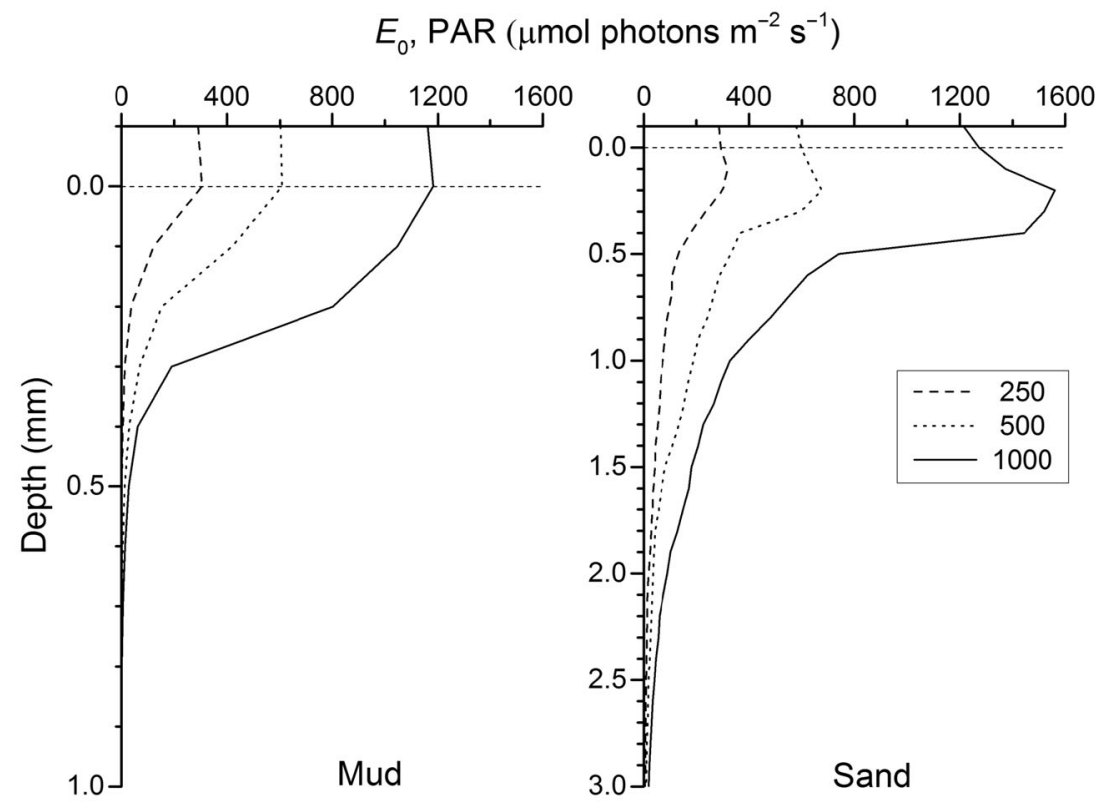

Fig. 2. Photon scalar irradiance depth microprofiles of photosynthetically available light $\left(E_{0}, \mathrm{PAR}_{i} \mu \mathrm{mol}\right.$ photons $\left.\mathrm{m}^{-2} \mathrm{~s}^{-1}\right)$ under different incident downwelling photon irradiances $\left(250,500\right.$ and $1000 \mu \mathrm{mol}$ photons $\left.\mathrm{m}^{-2} \mathrm{~s}^{-1}\right)$ of the muddy (mud) and sandy (sand) coastal sediments with a thicker DBL $(0.5-0.6 \mathrm{~mm})$ and with peak $\mathrm{O}_{2}$ concentrations at $0.5-$ $1.0 \mathrm{~mm}$ below the sediment surface, depending on the incident downwelling photon irradiance. At higher photon irradiance, the upper part of the sandy sediment reached $\mathrm{O}_{2}$ concentrations of $\sim 3$ times air saturation (Fig. 4).

$P_{\mathrm{z}}$ showed the highest rates of $\mathrm{O}_{2}$ production in the surface of the muddy sediment (Fig. 5), reaching $30.3 \pm 6.3 \mathrm{nmol} \mathrm{O}_{2} \mathrm{~cm}^{-3} \mathrm{~s}^{-1}$ under an incident downwelling photon irradiance of $1000 \mu \mathrm{mol}$ photons $\mathrm{m}^{-2} \mathrm{~s}^{-1}$. Photosynthesis rates decreased rapidly with depth, and photosynthetic $\mathrm{O}_{2}$ production was no longer detected below $0.6 \mathrm{~mm}$. In the sandy sediment, a subsurface maximum of gross photosynthesis rate of $8.5 \pm$ $3.8 \mathrm{nmol} \mathrm{O}_{2} \mathrm{~cm}^{-3} \mathrm{~s}^{-1}$ was observed at $0.1 \mathrm{~mm}$ under an incident down- ues of $8.65 \pm 0.40$ and $1.52 \pm 0.06 \mathrm{~mm}^{-1}$ for the muddy and sandy sediment, respectively.

Spectral attenuation of scalar irradiance increased from the infrared towards the blue part of the spectrum in both sediments (Fig. 3). Light attenuation for shorter wavelengths (400-50 nm) and around $675 \mathrm{~nm}$ (the absorption maxima of carotenoids and chlorophylls) was more pronounced in the muddy sediment. Spectral wavelengths outside the absorption bands of major diatom photopigments, especially in the near infrared region, penetrated deeper into the sediments (Fig. 3).

\section{$\mathrm{O}_{2}$, photosynthesis and respiration}

The $\mathrm{O}_{2}$ concentration profiles also differed between the 2 sediment types (Fig. 4). In the muddy sediment, $\mathrm{O}_{2}$ penetration increased with increasing irradiance from about $1.5 \mathrm{~mm}$ in the dark to 2.4 and $2.7 \mathrm{~mm}$ at 250 and $1000 \mu \mathrm{mol}$ photons $\mathrm{m}^{-2} \mathrm{~s}^{-1}$. The $\mathrm{O}_{2}$ concentration increased towards the muddy sediment surface, defining an approximately $0.3-0.4 \mathrm{~mm}$ thick DBL, and $\mathrm{O}_{2}$ concentrations reached a maximum immediately below the sediment surface $(0.1-$ $0.2 \mathrm{~mm}$ depth). At higher irradiance, the upper part of the muddy sediment reached $\mathrm{O}_{2}$ concentrations of $\sim 6$ times air saturation (Fig. 4). The $\mathrm{O}_{2}$ penetration in the sandy sediment was deeper than $4 \mathrm{~mm}$ (Fig. 4),

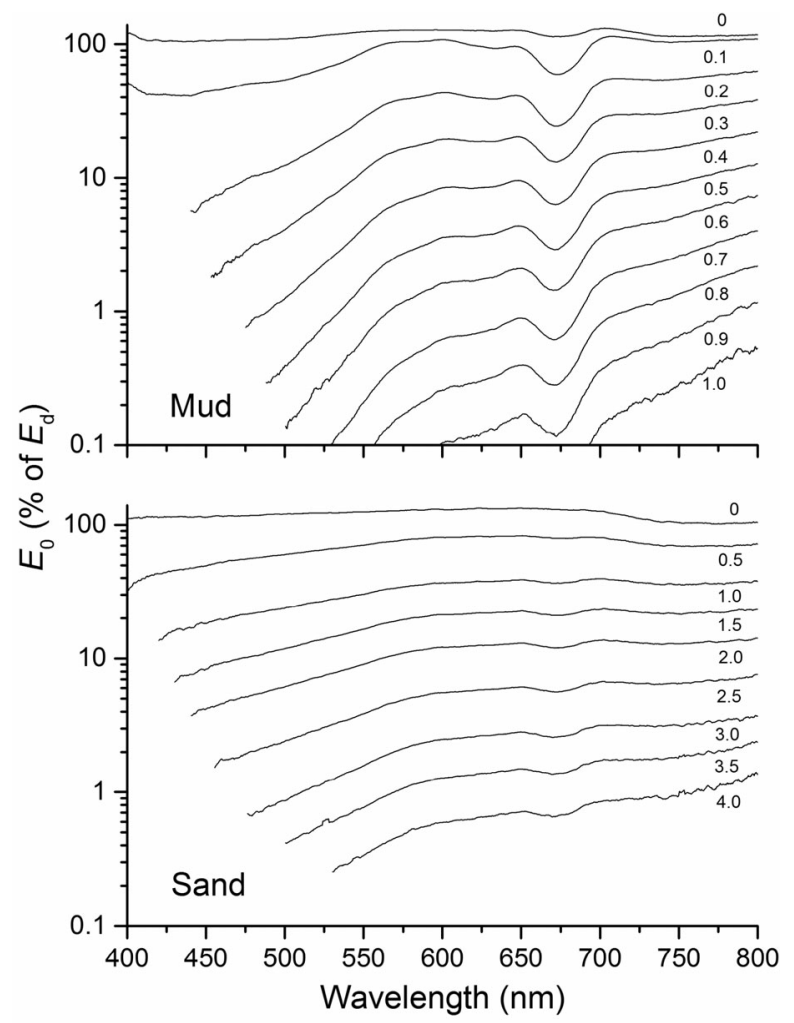

Fig. 3. Depth profiles of spectral scalar irradiance $\left(E_{0}\right)$ normalized to the downwelling irradiance at the sediment surface $\left(E_{\mathrm{d}}\right)$ of the muddy (mud) and sandy (sand) coastal sediments. Data are presented on a logarithmic scale and numbers indicate depth in $\mathrm{mm}$ 


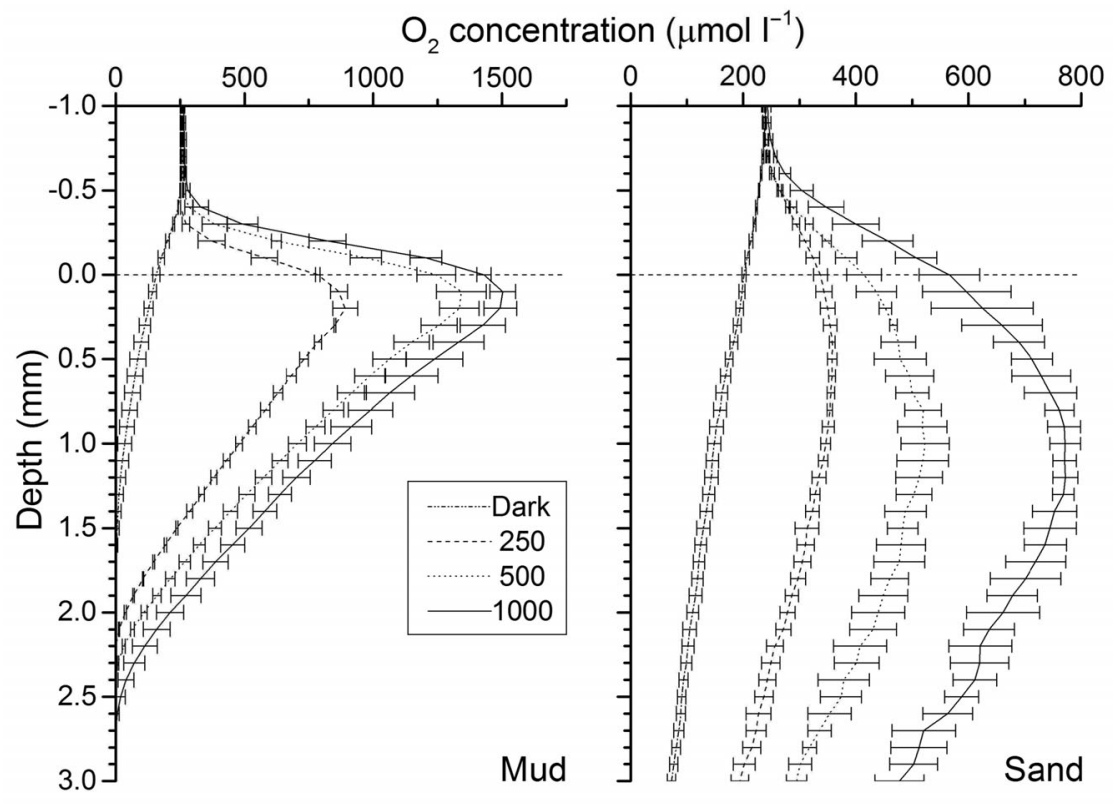

Fig. 4. Steady-state $\mathrm{O}_{2}$ depth microprofiles $\left(\mu \mathrm{mol} \mathrm{l}^{-1}\right.$; mean $\pm \mathrm{SD}, \mathrm{n}=3$ ) in the dark, and under different incident downwelling photon irradiances $(250,500$ and $1000 \mu \mathrm{mol}$ photons $\mathrm{m}^{-2} \mathrm{~s}^{-1}$ ) of the muddy (mud) and sandy (sand) coastal sediments

welling photon irradiance of $1000 \mu \mathrm{mol}$ photons $\mathrm{m}^{-2} \mathrm{~s}^{-1}$, followed by a decreasing photosynthetic $\mathrm{O}_{2}$ production with depth until $1.3 \mathrm{~mm}$ below the sand sediment surface. Under an incident downwelling photon irradiance of $1000 \mu \mathrm{mol}$ photons $\mathrm{m}^{-2} \mathrm{~s}^{-1}$, average volumetric gross photosynthesis rates in the photic zone were 10.5 and $3.0 \mathrm{nmol} \mathrm{O}_{2} \mathrm{~cm}^{-3} \mathrm{~s}^{-1}$

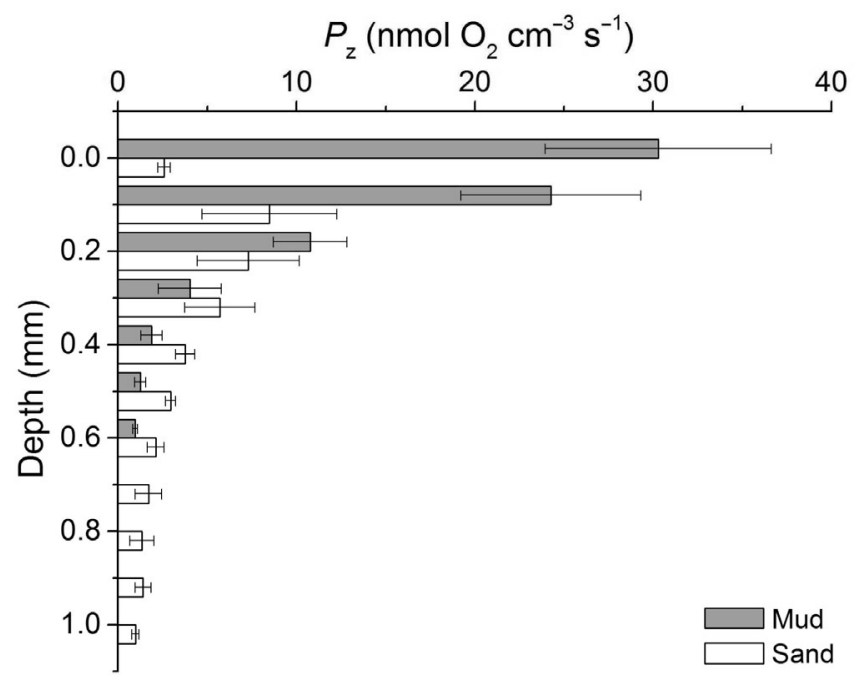

Fig. 5. Volumetric gross photosynthesis depth microprofiles $\left(P_{\mathrm{z} i} \mathrm{nmol} \mathrm{O}_{2} \mathrm{~cm}^{-3} \mathrm{~s}^{-1}\right.$, mean $\left.\pm \mathrm{SD}, \mathrm{n}=3\right)$ measured under an incident downwelling photon irradiance of $1000 \mu \mathrm{mol}$ photons $\mathrm{m}^{-2} \mathrm{~s}^{-1}$ for the muddy (mud) and sandy (sand) coastal sediments for the muddy and sandy sediments, respectively. $P_{\mathrm{g}}$ rates were higher for the muddy sediment $(0.698 \mathrm{nmol}$ $\mathrm{O}_{2} \mathrm{~cm}^{-2} \mathrm{~s}^{-1}$ ) compared to the sand $\left(0.242 \mathrm{nmol} \mathrm{O}_{2} \quad \mathrm{~cm}^{-2} \mathrm{~s}^{-1}\right) . \quad J_{\text {up }}$ and $J_{\text {down }}$ were higher in the muddy sediment, representing a total $\mathrm{O}_{2}$ export of $0.659 \mathrm{nmol} \mathrm{O} \mathrm{cm}^{-2} \mathrm{~s}^{-1}$, compared to only $0.109 \mathrm{nmol} \mathrm{O} \mathrm{Cm}^{-2} \mathrm{~s}^{-1}$ in the sandy sediment (Table 4).

$P_{\mathrm{n}}$ increased with incident photon irradiance for both studied sediments (Fig. 6). For the muddy sediment, net photosynthesis rates were much higher, reaching values of $0.56 \mathrm{nmol}$ $\mathrm{O}_{2} \mathrm{~cm}^{-2} \mathrm{~s}^{-1}$, and saturating at higher photon irradiance than in the sandy sediment, where the highest net photosynthesis rates achieved were $0.10 \mathrm{nmol} \mathrm{O}_{2} \mathrm{~cm}^{-2} \mathrm{~s}^{-1}$ (Fig. 6). From curve-fitting of $P_{\mathrm{n}}$ vs. photon irradiance data, $P_{\max }$ was estimated as 0.63 and $0.17 \mathrm{nmol} \mathrm{O}_{2} \mathrm{~cm}^{-2} \mathrm{~s}^{-1}$ for the muddy and sandy sediments, respectively. The corresponding $E_{\mathrm{k}}$ indexes, estimated from the interception of $P_{\max }$ and $\alpha$, were 314 and $966 \mu \mathrm{mol}$ photons $\mathrm{m}^{-2} \mathrm{~s}^{-1}$. The compensation irradiances (i.e. $E_{c i}$ the light at which the sediments became net $\mathrm{O}_{2}$-producing), were 20 and $60 \mu \mathrm{mol}$ photons $\mathrm{m}^{-2} \mathrm{~s}^{-1}$ for the muddy and sandy sediments, respectively.

$R_{\text {dark }}$ was highest for the muddy sediment, whereas $R_{\text {phot }}$ rates were highest in the sandy sediment (Table 4). Comparable areal respiratory rates under illuminated conditions were found in the 2 types of sediment (Table 4). Areal respiration rates measured in the light were considerably higher than in the dark. At a photon irradiance of $1000 \mu \mathrm{mol}$ photons

Table 4. Depth-integrated photosynthesis, oxygen fluxes and respiration (nmol $\mathrm{O}_{2} \mathrm{~cm}^{-2} \mathrm{~s}^{-1}$ ) estimated for $1000 \mu \mathrm{mol}$ photons $\mathrm{m}^{-2} \mathrm{~s}^{-1}$ of incident downwelling irradiance in the 2 studied diatom-dominated coastal sediment sites

\begin{tabular}{|lcc|}
\hline Areal rates $\left(\mathrm{nmol} \mathrm{O}_{2} \mathrm{~cm}^{-2} \mathrm{~s}^{-1}\right)$ & Mud & Sand \\
\hline Photosynthesis $\left(P_{\mathrm{g}}\right)$ & 0.698 & 0.242 \\
Upward $\mathrm{O}_{2}$ flux $\left(J_{\text {up }}\right)$ & 0.562 & 0.097 \\
Downward $\mathrm{O}_{2}$ flux $\left(J_{\text {down }}\right)$ & 0.097 & 0.012 \\
Total $\mathrm{O}_{2}$ export $\left(P_{\text {n,phot }}\right)$ & 0.659 & 0.109 \\
Respiration in the dark $\left(R_{\text {dark }}\right)$ & 0.038 & 0.010 \\
Respiration in the light $\left(R_{\text {light }}\right)$ & 0.136 & 0.145 \\
Photic zone respiration $\left(R_{\text {phot }}\right)$ & 0.039 & 0.133 \\
Aphotic zone respiration $\left(R_{\text {aphot }}\right)$ & 0.097 & 0.012 \\
\hline
\end{tabular}




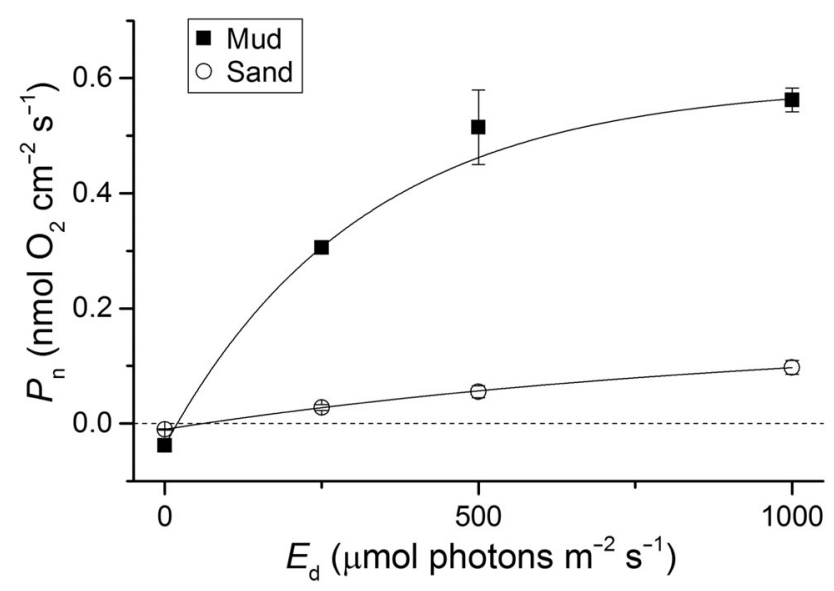

Fig. 6. Areal rates of net photosynthesis $\left(P_{\mathrm{n}}\right.$ nmol $\mathrm{O}_{2} \mathrm{~cm}^{-2}$ $\mathrm{s}^{-1}$, mean $\pm \mathrm{SD}, \mathrm{n}=3$ ) in the dark, and under different incident downwelling photon irradiances $(250,500$ and $1000 \mu \mathrm{mol}$ photons $\mathrm{m}^{-2} \mathrm{~s}^{-1}$ ) for the muddy (mud) and sandy (sand) coastal sediments. Solid lines represent curve fits to the data: $\mathrm{R}^{2}(\mathrm{mud})=0.998 ; \mathrm{R}^{2}($ sand $)=0.999$

$\mathrm{m}^{-2} \mathrm{~s}^{-1}$, areal respiration rates were 3.6 and 14.5 times higher than the areal dark respiration in muddy and sandy sediments, respectively. In the mud, areal respiration in the dark was $0.038 \mathrm{nmol} \mathrm{O}_{2} \mathrm{~cm}^{-2}$ $\mathrm{s}^{-1}$, whereas $\mathrm{O}_{2}$ penetrated down to $1.7 \mathrm{~mm}$. Therefore, the average volumetric $\mathrm{O}_{2}$ respiration in the dark was $0.038 / 0.17=0.22 \mathrm{nmol} \mathrm{O}_{2} \mathrm{~cm}^{-3} \mathrm{~s}^{-1}$. Accordingly, considering an $\mathrm{O}_{2}$ penetration of $4 \mathrm{~mm}$, average volumetric $\mathrm{O}_{2}$ respiration in the dark was $0.03 \mathrm{nmol} \mathrm{O}_{2} \mathrm{~cm}^{-3} \mathrm{~s}^{-1}$ in the sandy sediment. Areal $\mathrm{O}_{2}$ respiration rates within the photic zone were 0.039 and $0.133 \mathrm{nmol} \mathrm{O}_{2} \mathrm{~cm}^{-2} \mathrm{~s}^{-1}$ for mud and sand, respectively (Table 4). Considering the thicknesses of the photic zones $(0.6$ and $1.3 \mathrm{~mm}$ for mud and sand, respectively), average volumetric $\mathrm{O}_{2}$ respiration within the corresponding productive zones were 0.65 and $1.02 \mathrm{nmol} \mathrm{O}_{2} \mathrm{~cm}^{-3} \mathrm{~s}^{-1}$.

\section{DISCUSSION}

Photon scalar irradiance at the surface of both coastal sediment types was higher (about $120 \%$ ) than the incident downwelling irradiance due to intense light scattering in the uppermost sediment layers. In the sandy sediment, due to low light absorption and high scattering at the uppermost layers, a subsurface scalar irradiance maximum was observed reaching $150 \%$ of incident downwelling irradiance. This suggests that measurements of downwelling irradiance (the most commonly measured light parameter in benthic studies) can underestimate the total light intensity (i.e. the scalar irradiance) available for microbenthic phototrophs. Kühl et al. (1994) showed that measurements of downwelling irradiance can underestimate light availability by $>100 \%$. Although this represents an extreme value measured in highly scattering sand with little absorption, scalar irradiance in the visible part of the spectrum typically reaches about 110 to $160 \%$ of the incident irradiance at the surface of most photosynthetic biofilms and sediments (Kühl et al. 1997).

Scalar irradiance was attenuated exponentially with depth starting from the surface in the fine muddy sediment. The scalar irradiance attenuation coefficient reported here for the muddy sediment $\left(8.65 \pm 0.40 \mathrm{~mm}^{-1}\right)$ is among the highest described for benthic systems, comparable only to other highly cohesive, fine intertidal sediments (Cartaxana et al. 2011) and microbial mats (Kühl et al. 1997). In both sediments, strongest light attenuation was observed for wavelengths around $675 \mathrm{~nm}$ and in the $400-550 \mathrm{~nm}$ range, corresponding to absorption maxima of diatom photopigments (chlorophylls and carotenoids), especially in the muddy sediment. Such differential light absorption led to a decrease with depth of the wavelengths more relevant for photosynthesis, thus limiting photosynthetic activity in deeper sediment layers. Ploug et al. (1993) related these changes in light quality to the vertical zonation of a population of pennate diatoms over a dense underlying population of filamentous cyanobacteria that largely sustained their oxygenic photosynthesis via phycobiliproteins with absorption characteristics complementary to chlorophylls. At an incident downwelling photon irradiance of $1000 \mu \mathrm{mol}$ photons $\mathrm{m}^{-2} \mathrm{~s}^{-1}$, photon scalar irradiance values of about 6 and $200 \mu \mathrm{mol}$ photons $\mathrm{m}^{-2} \mathrm{~s}^{-1}$ were measured at the lower boundary of the photic zones in the muddy and sandy sediments, respectively. The relatively high light availability at the lower boundary of the sandy sediment photic zone may indicate that parameters other than light intensity may have limited photosynthesis. According to Kühl et al. (1996), the lower boundary of the photic zone in cyanobacterial mats could result from reduced light quality, nutrient limitation or the presence of toxic compounds such as sulfide.

Significantly higher areal rates of $\mathrm{O}_{2}$ consumption were found in illuminated sediments than in the dark. This could be the result of the observed gradual increase of both $\mathrm{O}_{2}$ concentration and penetration depth with irradiance as well as enhanced volumetric $\mathrm{O}_{2}$ respiration in and below the photic zone, resulting from a direct stimulation of heterotrophic processes (Kühl et al. 1996). A similar pattern of light-enhanced 
respiration has been observed in cyanobacterial mats (Kühl et al. 1996, Epping \& Kühl 2000), although the volumetric rates of respiration reported were 3 to 4 times higher than in both sediments studied here, indicating a lower heterotrophic activity in diatomdominated communities.

Areal and volumetric rates of photosynthesis were $\sim 3$ times higher in the muddy sediment, although the microphytobenthos biomass (chl a per volume on $2 \mathrm{~mm}$ depth samples) was similar in mud and sand. Hence, differences in the distribution of the biomass along the sediment profile and a thinner euphotic zone may explain the higher productivity of the muddy sediment. Microphytobenthos in muddy sediments has been shown to be highly stratified in the mud, with most of the chl a occurring in the top $0.5 \mathrm{~mm}$, while in sandy sediments relatively constant concentrations were found throughout the sediment profile down to a depth of several mm (Cartaxana et al. 2006). In relatively flat benthic systems, photosynthetic efficiency has been shown to be higher in sediments and biofilms with a thinner and more densely populated photic zone (Al-Najjar et al. 2012), as the one found in the muddy sediment we studied. The rationale is that the contribution of active photopigments to total light absorption relative to that of photosynthetic inactive components increases with augmented biomass and a thinner photic zone. On the other hand, light attenuation by sand grains and mineral precipitates was probably highly relevant in the sandy sediment, where the microphytobenthic cells were more dispersed and the photic zone was wider. Hence, maximum volumetric photosynthesis has been shown to correlate positively with light attenuation in sediments/biofilms and in other aquatic plant communities (Al-Najjar et al. 2012, KrauseJensen \& Sand-Jensen 1998). Our results contrast with those reported by Billerbeck et al. (2007), who showed higher photosynthetic rates in coarse and fine sands than in a muddy sediment.

Volumetric and areal rates of photosynthesis in the diatom-dominated muddy sediment were similar to maximum in situ rates measured in another mud flat of the Tagus estuary (Brotas et al. 2003). Maximum photosynthetic rates at saturating photon irradiances were higher in the muddy sediment than in cyanobacterial mats or cyanobacteria-diatom mixed biofilms (Kühl et al. 1996, Al-Najjar et al. 2010, 2012), but within the range compiled by Krause-Jensen \& Sand-Jensen (1998) for microalgal mats. A lower level of $E_{\mathrm{k}}$ was observed for the muddy sediment, corroborating the results of previous studies that mud flat diatom communities exhibit lower light acclima- tion compared to epipsammic-dominated sand flat communities (Jesus et al. 2009, Pniewski et al. 2015).

Both studied coastal sediments were dominated by diatoms exhibiting relative abundances $>90 \%$. However, the species composition was very distinct in that the 2 different microphytobenthic communities only shared 2 common diatom species. Sediment particle composition, defined largely by hydrodynamic forces that control local sediment deposition and erosion, has been shown to be the most important parameter determining diatom species composition in coastal sediments (Sabbe \& Vyverman 1991, Hamels et al. 1998, Paterson \& Hagerthey 2001, Ribeiro et al. 2013). Our results confirm previous reported patterns indicating that larger epipelic diatom and smaller epipsammic diatom species are more abundant in muddy and sandy sediments, respectively. However, half of the sand-dwelling diatoms were part of the epipelon, and medium size diatoms (250 to $1000 \mu^{3}$ ) dominated both muddy and sandy communities in terms of relative abundance. Diatom species richness and diversity were higher in the sandy sediment with the co-occurrence of motile epipelic and various forms of non-motile (i.e. adnate, stalked) and motile epipsammon. This could be related to the more diverse particle size composition of the sandy sediment and the sand-grain microtopography itself, allowing higher niche differentiation compared to the more homogeneous muddy sediment (Ribeiro et al. 2013).

Although both diatom communities were dominated by motile species in terms of relative abundance, the importance of motility for the photophysiology of the muddy sediment community was much more prevalent. The light gradient in the mud was much steeper, and typical free-moving epipelic diatoms would experience significant changes in photon irradiance simply by covering distances comparable to their cell size. On the other hand, the light environment in the sandy sediment was much more homogeneous, requiring cells to travel much longer distances to actively search for a different light microenvironment. Furthermore, movement in motile epipsammic species is highly limited, i.e. restricted to the sphere of individual sand grains or very slow movement from sand grain to sand grain (Round 1979). Finally, the higher hydrodynamic forcing in the sandy sediment causes a continuous rearrangement and sorting of the sand grains that distributes the epipsammon more evenly, whilst destroying or disrupting large accumulations of epipelic diatoms at certain depths (Delgado et al. 1991, Paterson \& Hagerthey 2001). Hence, the higher areal 
and volumetric rates of photosynthesis and higher maximum photosynthetic capacity observed in the muddy sediment could also be related to the capacity of epipelic diatoms in this sediment to actively search for optimal light microenvironments. Kromkamp et al. (1998) proposed a 'micromigration' mechanism, in which cells would be continuously replaced by others at the sediment surface, increasing light-use efficiency and preventing photoinhibition and $\mathrm{CO}_{2}$ limitation. Micromigration could thus represent a rapid, flexible and energetically cheap way for benthic diatoms to optimize productivity in fine grained sediments (Serôdio et al. 2001).

This work describes the major differences in light and $\mathrm{O}_{2}$ microenvironments of 2 diatom-dominated microphytobenthic communities inhabiting distinct substrata. We conclude that the higher photosynthetic rates observed in the fine muddy sediment were related to (1) the compaction of the productive biomass into a thin photic zone which reduces the absorption of light by inactive sediment components, and (2) differences in diatom species composition and dominant life-strategies, specifically the capacity of diatom cells to change their light microenvironment by moving within a steep irradiance gradient.

Acknowledgements. This study was supported by a grant from the Danish Council for Independent Research I Natural Sciences (M.K.). S.C. was supported by Fundação para a Ciência e a Tecnologia (IF/00899/2014). We thank Sofie Jakobsen for technical assistance, Lars Rickelt for manufacturing scalar irradiance microsensors, Mads Lichtenberg for help with the microprofiling set-up, and Carla Gameiro with sediment sampling in the Tagus estuary. We thank 2 anonymous reviewers for their critical comments on earlier drafts of the manuscript.

\section{LITERATURE CITED}

Admiraal W (1984) The ecology of estuarine sedimentinhabiting diatoms. In: Chapman DJ, Round FE (eds) Progress in phycological research. Biopress, Bristol, p 269-322

- Al-Najjar MA, de Beer D, Jørgensen BB, Kühl M, Polerecky L (2010) Conversion and conservation of light energy in a photosynthetic microbial mat ecosystem. ISME J 4: 440-449

> Al-Najjar MA, de Beer D, Kühl M, Polerecky L (2012) Light utilization efficiency in photosynthetic microbial mats. Environ Microbiol 14:982-992

Barnett A, Méléder M, Blommaert L, Lepetit B and others (2015) Growth form defines physiological photoprotective capacity in intertidal benthic diatoms. ISME J 9: $32-45$

Bellinger BJ, Underwood GJC, Ziegler SE, Gretz MR (2009) Significance of diatom derived polymers in carbon flow dynamics within estuarine biofilms determined through isotopic enrichment. Aquat Microb Ecol 55:169-187
Billerbeck M, Røy H, Bosselmann K, Huettel M (2007) Benthic photosynthesis in submerged Wadden Sea intertidal flats. Estuar Coast Shelf Sci 71:704-716

Brotas V, Risgaard-Petersen N, Serôdio J, Ottosen L, Dalsgaard T, Ribeiro L (2003) In situ measurements of photosynthetic activity and respiration of intertidal benthic microalgal communities undergoing vertical migration. Ophelia 57:13-26

> Cartaxana P, Mendes CR, van Leeuwe MA, Brotas V (2006) Comparative study on microphytobenthic pigments of muddy and sandy intertidal sediments of the Tagus estuary. Estuar Coast Shelf Sci 66:225-230

Cartaxana P, Ruivo M, Hubas C, Davidson I, Serôdio J, Jesus B (2011) Physiological versus behavioral photoprotection in intertidal epipelic and epipsammic benthic diatom communities. J Exp Mar Biol Ecol 405:120-127

Delgado M, de Jonge VN, Peletier H (1991) Effect of sand movement on the growth of benthic diatoms. J Exp Mar Biol Ecol 145:221-231

Epping E, Kühl M (2000) The responses of photosynthesis and oxygen consumption to short-term changes in temperature and irradiance in a cyanobacterial mat (Ebro Delta, Spain). Environ Microbiol 2:465-474

Glud RN, Ramsing NB, Revsbech NP (1992) Photosynthesis and photosynthesis-coupled respiration in natural biofilms quantified with oxygen microsensors. J Phycol 28: 51-60

Glud RN, Kühl M, Wenzhöfer F, Rysgaard S (2002) Benthic diatoms of a high Artic fjord (Young Sound, NE Greenland): importance for ecosystem primary production. Mar Ecol Prog Ser 238:15-29

Hamels I, Sabbe K, Muylaert K, Barranguet C, Lucas C, Herman P, Vyverman W (1998) Organisation of microbenthic communities in intertidal estuarine flats, a case study from the Molenplaat (Westerschelde estuary, The Netherlands). Eur J Protistol 34:308-320

Hancke K, Glud RN (2004) Temperature effects on respiration and photosynthesis in three diatom-dominated benthic communities. Aquat Microb Ecol 37:265-281

Hillebrand C, Dürselen CD, Kirschtel D, Pollingher U, Zohary $\mathrm{T}$ (1999) Biovolume calculation for pelagic and benthic microalgae. J Phycol 35:403-424

$>$ Iversen N, Jørgensen BB (1993) Diffusion coefficients of sulfate and methane in marine sediments: influence of porosity. Geochim Cosmochim Acta 57:571-578

Jeffrey SW, Humphrey GF (1975) New spectrophotometric equations for determining chlorophylls $a, b, c_{1}$ and $c_{2}$ in higher plants, algae and natural phytoplankton. Biochem Physiol Pflanz 167:191-194

- Jesus B, Brotas V, Ribeiro L, Mendes CR, Cartaxana P, Paterson DM (2009) Adaptations of microphytobenthos assemblages to sediment type and tidal position. Cont Shelf Res 29:1624-1634

Krause-Jensen D, Sand-Jensen K (1998) Light attenuation and photosynthesis of aquatic plant communities. Limnol Oceanogr 43:396-407

Kromkamp J, Barranguet C, Peene J (1998) Determination of microphytobenthos PSII quantum efficiency and photosynthetic activity by means of variable chlorophyll fluorescence. Mar Ecol Prog Ser 162:45-55

Kühl M (2005) Optical microsensors for analysis of microbial communities. Methods Enzymol 397:166-199

Kühl M, Jørgensen BB (1992) Spectral light measurements in microbenthic phototrophic communities with a fiberoptic microprobe coupled to a sensitive diode array 
detector. Limnol Oceanogr 37:1813-1823

Kühl M, Jørgensen BB (1994) The light-field of microbenthic communities: radiance distribution and microscale optics of sandy coastal sediments. Limnol Oceanogr 39: 1368-1398

Kühl M, Lassen C, Jørgensen BB (1994) Light penetration and light intensity in sandy marine sediments measured with irradiance and scalar irradiance fiber-optic microprobes. Mar Ecol Prog Ser 105:139-148

Kühl M, Glud RN, Ploug H, Ramsing NB (1996) Microenvironmental control of photosynthesis and photosynthesis-coupled respiration in an epilithic cyanobacterial biofilm. J Phycol 32:799-812

Kühl M, Lassen C, Revsbech NP (1997) Simple light meter for measurements of PAR (400 to $700 \mathrm{~nm}$ ) with fiber-optic microprobes: application for $P$ vs $E_{0}(\mathrm{PAR})$ measurements in a microbial mat. Aquat Microb Ecol 13:197-207

Lassen C, Ploug H, Jørgensen BB (1992) Microalgal photosynthesis and spectral scalar irradiance in coastal marine sediments of Limfjorden, Denmark. Limnol Oceanogr 37: 760-772

MacIntyre HL, Geider RJ, Miller DC (1996) Microphytobenthos: the ecological role of the 'secret garden' of unvegetated, shallow-water marine habitats. 1. Distribution, abundance and primary production. Estuaries 19: 186-201

Paterson DM, Hagerthey SE (2001) Microphytobenthos in contrasting coastal ecosystems: biology and dynamics. In: Reise K (ed) Ecological comparisons of sedimentary shores. Springer-Verlag, Berlin, p 105-25

Perkins RG, Lavaud J, Serôdio J, Mouget JL and others (2010) Vertical cell movement is a primary response of intertidal benthic biofilms to increasing light dose. Mar Ecol Prog Ser 416:93-103

Pinckney J, Zingmark RG (1991) Effects of tidal stage and sun angles on intertidal benthic microalgal productivity. Mar Ecol Prog Ser 76:81-89

Ploug H, Lassen C, Jørgensen BB (1993) Action spectra of microalgal photosynthesis and depth distribution of spectral scalar irradiance in a coastal marine sediment of Limfjorden, Denmark. FEMS Microbiol Ecol 12:69-78

Pniewski FF, Biskup P, Bubak I, Richard P, Latala A, Blanchard G (2015) Photoregulation in microphytobenthos from intertidal mudflats and non-tidal coastal shallows. Estuar Coast Shelf Sci 152:153-161

Revsbech NP, Jørgensen BB (1983) Photosynthesis of benthic microflora measured with high spatial resolution by the oxygen microprofile method: capabilities and limitations of the method. Limnol Oceanogr 28:749-756

Ribeiro L (2010) Intertidal benthic diatoms of the Tagus estuary: taxonomic composition and spatial-temporal variation. PhD dissertation, University of Lisbon

Ribeiro L, Brotas V, Rincé Y, Jesus BM (2013) Structure and diversity of intertidal benthic diatom assemblages in con-

Editorial responsibility: Ronald Kiene,

Mobile, Alabama, USA trasting shores: a case study from the Tagus estuary. J Phycol 49:258-270

Rickelt LF, Lichtenberg M, Trampe E, Kühl M (2016) Fiberoptic probes for small scale measurements of scalar irradiance. Photochem Photobiol, doi:10.1111/php.12560

Round FE (1965) The epipsammon; a relatively unknown freshwater algal association. Brit Phycol Bull 2:456-462

- Round FE (1979) A diatom assemblage living below the surface of intertidal sand flats. Mar Biol 54:219-223

$>$ Round FE, Palmer JD (1966) Persistent, vertical-migration rhythms in benthic microflora. II. Field and laboratory studies on diatoms from the banks of the River Avon. J Mar Biol Assoc UK 46:191-214

Sabbe K, Vyverman W (1991) Distribution of benthic diatom assemblages in the Westerschelde (Zeeland, The Netherlands). Belg J Bot 124:91-101

> Serôdio J, Marques da Silva J, Catarino F (2001) Use of in vivo chlorophyll a fluorescence to quantify short-term variations in the productive biomass of intertidal microphytobenthos. Mar Ecol Prog Ser 218:45-61

Snoeijs P, Busse S, Potapova M (2002) The importance of diatom cell size in community analysis. J Phycol 38: 265-272

Spilling K, Titelman J, Greve TM, Kühl M (2010) Microsensor measurements of the external and internal microenvironments of Fucus vesiculosus (Phaeophyceae). J Phycol 46:1350-1355

Sundbäck K, Miles A, Goransson E (2000) Nitrogen fluxes, denitrification and the role of microphytobenthos in microtidal shallow-water sediments: an annual study. Mar Ecol Prog Ser 200:59-76

Underwood GJC, Kromkamp J (1999) Primary production by phytoplankton and microphytobenthos in estuaries. Adv Ecol Res 29:93-153

> Underwood GJC, Paterson DM (2003) The importance of extracellular carbohydrate production by marine epipelic diatoms. Adv Bot Res 40:183-240

> Underwood GJC, Perkins RG, Consalvey MC, Halon ARM, Oxborough K, Baker NR, Paterson DM (2005) Patterns in microphytobenthic primary productivity: species-specific variation in migratory rhythms and photosynthetic efficiency in mixed-species biofilms. Limnol Oceanogr 50:755-767

Vieira S, Utkin A, Lavrov A, Santos NM, Vilar R, Marques da Silva J, Cartaxana P (2011) Effects of intertidal microphytobenthos migration on biomass determination via laser-induced fluorescence. Mar Ecol Prog Ser 432:45-52

$>$ Webb WL, Newton M, Starr D (1974) Carbon-dioxide exchange of Alnus rubra: a mathematical model. Oecologia 17:281-291

Witkowski A, Lange-Bertalot H, Metzeltin D (2000) Diatom flora of marine coasts, Vol 1. In: Lange-Bertalot H (ed) Iconographia Diatomologica: annotated diatom micrographs. Koeltz Scientific Books, Königstein

Submitted: November 4, 2015; Accepted: January 22, 2016 Proofs received from author(s): February 22, 2016 